\title{
STUDY OF TESTS FOR TREND IN TIME SERIES
}

\author{
Denise de Assis PAIVA ${ }^{1}$ \\ Thelma SÁFADI ${ }^{1}$
}

- ABSTRACT: The time series methodology is an important tool when using data over time. The time series can be composed of the components trend $\left(T_{t}\right)$, seasonality $\left(S_{t}\right)$ and the random error $\left(a_{t}\right)$. The aim of this study was to evaluate the tests used to analyze the trend component, which were: Pettitt, Run, Mann-Kendall, Cox-Stuart and the unit root tests (Dickey-Fuller, Dickey-Fuller Augmented and Zivot and Andrews), given that there is a discrepancy between the test results found in the literature. The four series analyzed were the maximum temperature in the Lavras city, MG, Brazil, the unemployment rate in the Metropolitan Region of São Paulo (RMSP), the Broad Consumer Price Index (IPCA) and the nominal Gross Domestic Product (GDP) of Brazil. It was found that the unit root tests showed similar results in relation to the presence of the stochastic trend for all series. Furthermore, the turning point of the Pettitt test diverged from all the structural breaks found through the Zivot and Andrews test, except for the GDP series. Therefore, it was found that the trend tests diverged, obtaining similar results only in relation to the unemployment series.

- KEYWORDS: Economic series; temperature series; stochastic and deterministic trend.

\section{Introduction}

The time series methodology can be applied to several areas, being an important tool when using data over time and that are correlated. According to Morettin and Toloi (2018), a time series $Z(t)$ is any set of observations ordered in time and equally spaced.

In addition, a characteristic of the analysis of the series is that its study can be conducted in the time domain (parametric models) or in the frequency domain (non-parametric models). In many cases, the researcher is interested in

\footnotetext{
${ }^{1}$ Universidade Federal de Lavras - UFLA, Departamento de Estatística, Caixa Postal: 3037, CEP: 37200-900, Lavras, MG, Brasil. E-mail: denisepaiva1310@gmail.com; safadi@ufla.br
}

Rev. Bras. Biom., Lavras, v.39, n.2, p.311-333, 2021 - doi: 10.28951/rbb.v39i2.471 
investigating the generating mechanism of the time series, making predictions of future values, describing its behavior or looking for relevant periodicities in the data (MORETTIN; TOLOI, 2018).

Considering a time series that is composed of three components: trend $\left(T_{t}\right)$, seasonality $\left(S_{t}\right)$ and random error $\left(a_{t}\right)$, the interest in this study is to analyze some tests that are able of detecting the trend component in the series.

The trend tests studied here were: Pettitt, Run, Mann-Kendall, Cox-Stuart tests and unit root tests (Dickey-Fuller test, Augmented Dickey-Fuller (ADF) and Zivot and Andrews (ZA)). Among the tests mentioned, the first four are non-parametric tests and the unit root tests are parametric.

There are many studies who apply these trend tests in several areas, for example, the Mann-Kendall test widely used in the climatological area (SALVIANO et al., 2016). The unit root test, on the other hand, is usually for the analysis of financial data (LIMA et al., 2013; POERSCHKE; MORAIS, 2014).

There are also other areas in which the time series methodology can be used in order to analyze the trend component, as in medicine (electrocardiogram levels), in epidemiology (ANTUNES; CARDOSO, 2015), among others.

Thus, there is an importance in detecting the trend component, because it is possible to verify whether the observations show increase, decrease or if they remain constant over time, besides being possible to investigate the causes of these variations.

In this way, the aim of this study was to compare the tests usually used to analyze the trend component. In addition, to identify characteristics of the series under study, such as trend and seasonality, considering the implications of what is

being tested, given that there is a discrepancy between the test results found in the literature.

For this, four time series were used, temperature in the city of Lavras, MG, Brazil, unemployment rate in the Metropolitan Region of São Paulo, Broad Consumer Price Index (IPCA) and Brazil nominal Gross Domestic Product (GDP).

\section{Material and methods}

\subsection{Description of the data}

For the analysis, four databases were used:

- maximum temperature in the city of Lavras-MG available at the site of the National Institute of Meteorology, totaling 1038 daily observations from 01/01/2017 to 11/04/2019 (Source: National Institute of Meteorology (INMET));

- unemployment rate in the Metropolitan Region of São Paulo from December 1984 to June 2019, totaling 415 monthly observations, available at the 
site of the Institute of Applied Economic Research (Source: State System of Data Analysis Foundation), Employment and Unemployment Survey (Seade/PED));

- Broad National Consumer Price Index available at the site of the Institute of Applied Economic Research, totaling 295 monthly observations from April 1995 to October 2019 (Source: Brazilian Institute of Geography and Statistics, National System of Consumer Price Indexes (IBGE/SNIPC));

- Nominal Brazilian Gross Domestic Product (in dollars) from 12/31/1960 to 12/31/18 totaling 59 observations, available in the BETS package of software R (R CORE TEAM, 2019) (Source: The series available through this package are prepared by three influential centers: the Central Bank of Brazil (BCB), the Brazilian Institute of Geography and Statistics (IBGE) and the Brazilian Institute of Economics, of the Getulio Vargas Foundation (FVG-IBRE)).

\section{$2.2 \quad$ Trend tests}

A time series $Z_{t}$ can be described in additive or multiplicative form. The series is presented below in its additive form (equation 1):

$$
Z_{t}=T_{t}+S_{t}+a_{t}
$$

where $T_{t}$ is the trend, $S_{t}$ is seasonality and $a_{t}$ is the random component (average 0 and variance $\sigma^{2}$ ), for $t=1,2, \ldots, N$.

In addition, it is known that there are two kinds of trends, namely, deterministic and stochastic trends. From this, some trend tests that were used in this study are presented.

It is important to note that four of the tests mentioned are non-parametric, and therefore, it is not necessary to specify the distribution of the population from which the sample comes. They are: Pettitt test, Mann-Kendall test and Cox-Stuart test. The unit root tests (Dickey-Fuller, ADF and Zivot and Andrews) are parametric tests, with the ADF test being a generalization of the Dickey-Fuller test.

\subsubsection{Pettitt test}

The Pettitt test is a non-parametric test that analyzes whether two samples $Z_{1}, \ldots, Z_{t}$ and $Z_{t+1}, \ldots, Z_{N}$ come from the same population (PETTITT, 1979).

Thus, the hypotheses to be tested are:

$$
\left\{\begin{array}{l}
H_{0}: \text { data are homogeneous (absence of a change point) } \\
H_{1}: \text { data are not homogeneous (change point). }
\end{array}\right.
$$

By means of the statistic $U_{t, N}$ under $H_{0}$, it is count the number of times an element of the first sample is greater than an element of the second, which can be 
written as

$$
U_{t, N}=U_{t-1, N}+\sum_{j=1}^{N} \operatorname{signal}\left(Z_{t}-Z_{j}\right), \mathrm{t}=2, \ldots, \mathrm{N} .
$$

being,

$$
\operatorname{signal}\left(Z_{t}-Z_{j}\right)=\left\{\begin{array}{l}
+1, \text { if } Z_{t}-Z_{j}>0 \\
0, \text { if } Z_{t}-Z_{j}=0 \\
-1, \text { if } Z_{t}-Z_{j}<0
\end{array}\right.
$$

To find the point of change (point change) of a series and its significance, the following equations are used:

$$
k_{t}=\max _{1 \leq t \leq N}\left|U_{t, N}\right|
$$

and

$$
p \approx 2 \exp \left(\frac{-6\left(k_{N}\right)^{2}}{N^{3}+N^{2}}\right)
$$

being that the $k_{t}$ statistic represents the point of change $t$ at which the value of $\left|U_{t, N}\right|$ is maximum and is associated with the significance level $p, k_{N}$, which is the critical value, $N$ is the number of observations of the series.

According to Penereiro and Meschiatti (2018), the point of sudden change is that in which the value of $t$ occurs to the maximum (or minimum) value of $k(t)$, obtained through the inversion of the previous equation, resulting in the following equation:

$$
k_{\text {crit }}= \pm \sqrt{\frac{-\ln (p / 2)\left(N^{3}+N^{2}\right)}{6}} .
$$

Furthermore, the rejection of the stationarity condition is interpreted as a break and not a trend (NIEL et al., 1998). This means that the Pettitt test does not guarantee that a series presents the trend component, but rather a point of change, that is, the location of a break in the series.

\subsubsection{Run Test}

The Run test is also known as the Wald-Wolfowitz sequences test and verifies whether a series of data was generated randomly (MORETTIN; TOLOI, 2018).

The hypotheses are:

$$
\left\{\begin{array}{l}
H_{0}: \text { the sequence was generated randomly (no trend) } \\
H_{1}: \text { the sequence was not generated randomly (has a trend). }
\end{array}\right.
$$

The $T_{1}$ statistic uses the values above and below the median. First, it is considered $N$ the number of observations in a series. Then, these values are ordered and the symbol $A$ is assigned when the observation value is greater than or equal to the median, $A \geq m$, and the symbol $B$ if the value is less than the median, $B<m$. 
The total number of observations is $N=\left(n_{1}\right.$ points A $)+\left(n_{2}\right.$ points B), with the statistic $T_{1}$ equal to the number of sequences or number of runs.

The value of $T_{1}$ is obtained by counting the number of equal sequences, that is, the number of oscillations in the data set between the values $A$ and $B$. For example, suppose the number of observations is equal to 20. Among these observations, the first 5 values were equal to $A$, the next 6 were equal to $B$ and the other values equal to $A$ again. Then, 3 sequences $(A B A)$ were obtained, that is, the number of sequences (or runs) is equal to 3 .

According to Morettin and Toloi (2018), in the case of few sequences in relation to the series, the null hypothesis $H_{0}$ is rejected. For values of $n_{1}$ or $n_{2}>20$, the normal distribution is used under $H_{0}$, that is, $T_{1} \sim N\left(\mu, \sigma^{2}\right)$, where

$$
\begin{gathered}
\mu=\frac{2 n_{1} n_{2}}{N}+1, \\
\sigma=\sqrt{\frac{2 n_{1} n_{2}\left(2 n_{1} n_{2}-N\right)}{N^{2}(N-1)} .} .
\end{gathered}
$$

Through the calculations of $\mu$ and $\sigma$, one can find the value of the $\mathrm{Z}$ statistic given by:

$$
Z=\frac{T_{1}-\mu}{\sigma}
$$

Analyzing the value of $Z, H_{0}$ is rejected if $|Z|>Z_{\frac{\alpha}{2}}$, being $\alpha$ the significance level adopted.

\subsubsection{Mann-Kendall test}

According to Goossens and Berger (1986, apud Back (2001)), the MannKendall test (Mann (1945)) is the most appropriate to analyze climate changes in climatological series, being a method used to determine whether a data series has a time trend of statistically significant alteration.

From this, given a series $Z_{t}=\left\{Z_{1}, Z_{2}, \ldots, Z_{i}, \ldots, Z_{N}\right\}$, the test hypotheses are:

$$
\left\{\begin{array}{l}
H_{0}: \text { there is no trend in the data series } \\
H_{1}: \text { there is a trend in the data series. }
\end{array}\right.
$$

The $\mathrm{S}$ statistic is given by:

$$
S=\sum_{i=1}^{N-1} \sum_{j=i+1}^{N} \operatorname{signal}\left(Z_{j}-Z_{i}\right)
$$

where $Z_{i}$ represents the series values, $i$ and $j$ are the time indexes and $N$ is the number of elements in the series. The sign $\left(Z_{j}-Z_{i}\right)$ is analyzed, pair by pair, of all values in the $Z_{i}$ series in relation to the values that are future $Z_{j}$, being 


$$
\operatorname{signal}\left(Z_{j}-Z_{i}\right)=\left\{\begin{array}{l}
+1, \text { if } Z_{j}-Z_{i}>0 \\
0, \text { if } Z_{j}-Z_{i}=0 \\
-1, \text { if } Z_{j}-Z_{i}<0 .
\end{array}\right.
$$

According to Moreira and Naghettini (2016), for data without linked elements (equal values), the test statistic presents mean $E(S)$ and variance $\operatorname{Var}(S)$ given by:

$$
\begin{gathered}
E[S]=0, \\
\operatorname{Var}[S]=\frac{N(N-1)(2 N+5)}{18} .
\end{gathered}
$$

If linked points occur, the variance is corrected by the following expression

$$
\operatorname{Var}[S]=\frac{N(N-1)(2 N+5)-\sum_{t=1}^{N} t(t-1)(2 t+5)}{18}
$$

where $t$ is the number of linked index points $t=1, \ldots, N$.

According to Barbieri et al. (2017), when the number of observations $N$ of the series is large, the distribution of $S$ tends toward the normal distribution.

Obtained the values of the mean and variance, considering the established conditions, the value of the statistic $Z$ under $H_{0}$ is given by:

$$
Z=\left\{\begin{array}{l}
\frac{S-1}{\sqrt{\operatorname{Var}(S)}}, \text { if } S>0 \\
0, \text { if } S=0 \\
\frac{S+1}{\sqrt{\operatorname{Var}(S)}}, \text { if } S<0 .
\end{array}\right.
$$

The null hypothesis $H_{0}$ is rejected, if $|Z|>Z_{\frac{\alpha}{2}}$. If $H_{0}$ is rejected, the sign of the $Z$ statistic is analyzed, concluding whether the trend is positive $(Z>0)$ or negative $(Z<0)$.

In addition, according to Penereiro and Orlando (2013), the combined MannKendall and Pettitt tests are used, that is, performing analyses together so that it is possible to identify and locate when a possible trend in the time series started to exist.

\subsubsection{Cox-Stuart test}

The Cox-Stuart test, also known as the signal test, is used to verify monotonous series, that is, increasing or decreasing (AMARAL, 2014).

The application of the signal test considers $N$ observations grouped in pairs $\left(Z_{1}, Z_{c+1}\right), \ldots,\left(Z_{N-c}, Z_{N}\right)$. If the number of observations is even, $c=\frac{N}{2}$, but if the number of observations is odd, $c=\frac{N+1}{2}$. For each pair $\left(Z_{i}, Z_{i+c}\right)$, it is associate 
the sign + for $\left(Z_{i}<Z_{i+c}\right)$ and the sign - for $\left(Z_{i}>Z_{i+c}\right)$, eliminating ties. That is, for each pair the value of the first observation is compared with the value of the second observation, assigning the symbol according to the corresponding sign.

The hypotheses are:

$$
\begin{cases}H_{0}: P\left(Z_{i}<Z_{i+c}\right)=P\left(Z_{i}>Z_{i+c}\right), \forall i, & \text { there is no trend } \\ H_{1}: P\left(Z_{i}<Z_{i+c}\right) \neq P\left(Z_{i}>Z_{i+c}\right), \forall i, & \text { there is a trend. }\end{cases}
$$

Subsequently, $n$ is adopted equal to the number of pairs in which $Z_{i} \neq Z_{i+c}$. Therefore, for a value of $n \leq 20$ the decision rule is based on the binomial distribution and, $n>20$, the normal approximation is used (MORETTIN; TOLOI, 2018).

According to Wackerly et al. (2014), considering $M$ the number of positive differences, that is, the number of pairs with $+\operatorname{sign}$, the $Z$ statistic of the test approximating the normal distribution under $H_{0}$ is given per:

$$
Z=\frac{M-n p}{\sqrt{n p q}}
$$

where $p=q=\frac{1}{2}$.

Thus, $H_{0}$ is rejected if $|Z|>Z_{\frac{\alpha}{2}}$.

\subsubsection{Dickey-Fuller test}

There are several tests to verify the presence of a unit root, among them there is the Dickey-Fuller test (DF) proposed by Dickey and Fuller (1979) and the Augmented Dickey-Fuller test (ADF), which is an extension of the test DF, also proposed by Dickey and Fuller (1981).

According to Alves (2008), the objective of unit root tests is essentially to detect whether a given series has been sufficiently differentiated to become stationary.

Consider the $Z_{t}$ series characterized by the following process

$$
Z_{t}=\rho Z_{t-1}+a_{t} \quad-1 \leq \rho \leq 1
$$

where $a_{t} \sim R B\left(0, \sigma^{2}\right)$ ( $a_{t}$ is a random component that follows a white noise with zero mean and constant variance). When the value of $\rho=1$, the equation 17 , becomes a random walk model (without displacement) and then the process has a unit root and the series is said to be non-stationary.

If $|\rho|<1$, the time series $Z_{t}$ is said to be stationary and consequently does not have a unit root. Therefore, is tested $\rho=1$ or $\rho \neq 1$.

According to Maddala and Kim (1998), however, the $t$ test cannot be used to test $\rho=1$ in the equation 17 because, under the null hypothesis, $Z_{t} \sim I(1)\left(Z_{t}\right.$ is integrated in order 1 ) and therefore the $t$-statistic does not have an asymptotic normal distribution. Therefore, it is necessary to reformulate this equation: 


$$
Z_{t}-Z_{t-1}=\rho Z_{t-1}-Z_{t-1}+a_{t}=(\rho-1) Z_{t-1}+a_{t}
$$

rewriting the equation 18 , we have to

$$
\Delta Z_{t}=\delta Z_{t-1}+a_{t}
$$

where $\Delta$ is the difference operator and $\delta=(\rho-1)$.

Then, using the equation 19, Dickey and Fuller (1979) considered three different regression equations that can be used to test the presence of a unit root. In addition, according to Enders (2008), the difference between the three regressions concerns the presence of the deterministic elements $\beta_{1}$ e $\beta_{2}$ :

$Z_{t}$ is a random walk:

$$
\Delta Z_{t}=\delta Z_{t-1}+a_{t}
$$

$Z_{t}$ is a random walk with displacement:

$$
\Delta Z_{t}=\beta_{1}+\delta Z_{t-1}+a_{t}
$$

$Z_{t}$ is a random walk with displacement around a deterministic trend:

$$
\Delta Z_{t}=\beta_{1}+\beta_{2} t+\delta Z_{t-1}+a_{t}
$$

where $\beta_{1}$ and $\beta_{2}$ are constant and $t$ is the trend variable.

In each case, the hypotheses to be tested are:

$$
\left\{\begin{array}{l}
H_{0}: \delta=0, \text { there is at least one root within the unit circle } \\
H_{1}: \delta<0, \text { there are no roots within the unit circle. }
\end{array}\right.
$$

If the null hypothesis is rejected being $Z_{t}$ a random walk, it means that it is stationary with zero mean. In the case where $Z_{t}$ is a random walk with displacement, the stationary series with a mean other than zero is considered. If $Z_{t}$ is a random walk with displacement around a deterministic trend, $\delta<0$ (no stochastic trend) and $\beta_{2} \neq 0$ (the existence of a deterministic trend) are tested.

Thus, to obtain the value of the test statistic $(\tau)$, one should start by estimating one of the equations: 19 or 20 or 21 , by the OLS method. Subsequently, the estimated coefficient of $Z_{t-1}$ is divided in each case by its standard error to obtain the statistic $\tau$ as follows

$$
\tau=\frac{\hat{\delta}}{s(\hat{\delta})}
$$

where

$$
s(\hat{\delta})=\frac{S}{\left(\sum_{t=2}^{n} Z_{t-1}^{2}\right)^{1 / 2}}
$$


and

$$
S^{2}=\frac{1}{n-2} \sum_{t=2}^{n}\left(\Delta Z_{t}-\hat{\delta} Z_{t-1}\right)^{2}
$$

is the estimator of $\sigma^{2}$ in the regression of the equation 19 .

According to Morettin and Toloi (2018), if the calculated value $\tau$ is less than the critical value in the Dickey-Fuller statistics, the null hypothesis is rejected. But, if the value of the $\tau$ statistic is greater than the critical value, the null hypothesis that $\delta=0$ is not rejected and, therefore, there is at least one root within the unit circle.

\subsubsection{Augmented Dickey-Fuller Test}

In the DF test it is assumed that the errors are uncorrelated, that is, that the covariance between $a_{t}$ and $a_{t-k}$ for all $k>0$ is null. Thus, it is necessary to verify whether the regression residues are autocorrelated after applying the test. If this hypothesis is not met, the amplitude of the DF test is increased with the inclusion of a greater number of differences lags.

In this sense, Dickey and Fuller (1981) developed another test known as the Augmented Dickey-Fuller test (ADF test). The ADF is performed by extending the $3(19,20$ e 21$)$ adding the lagged values of the dependent variable $\Delta Z_{t}$, where:

$Z_{t}$ is a random walk:

$$
\Delta Z_{t}=\delta Z_{t-1}+\sum_{i=1}^{m} \alpha_{i} \Delta Z_{t-i}+\epsilon_{t}
$$

$Z_{t}$ is a random walk with displacement:

$$
\Delta Z_{t}=\beta_{1}+\delta Z_{t-1}+\sum_{i=1}^{m} \alpha_{i} \Delta Z_{t-i}+\epsilon_{t}
$$

$Z_{t}$ is a random walk with displacement around a deterministic trend:

$$
\Delta Z_{t}=\beta_{1}+\beta_{2} t+\delta Z_{t-1}+\sum_{i=1}^{m} \alpha_{i} \Delta Z_{t-i}+\epsilon_{t}
$$

where $\epsilon_{t} \sim R B$ ( $\epsilon_{t}$ is an uncorrelated random component) and $\Delta Z_{t-i}=Z_{t-i}-$ $Z_{t-i-1}$.

According to Burke (1994, apud Maddala and Kim (1998)), the objective of the $\mathrm{ADF}$ test is to use the smallest number of lags that guarantee the non-correlation of the residues, so the value of $m$ is chosen which minimizes the Akaike information criterion statistic (AIC). According to this criterion, the best adjusted model is the one with the lowest value.

The hypotheses and statistics for the ADF test are the same as those used in the Dickey-Fuller test. 


\subsubsection{Zivot and Andrews test}

In addition to the traditional unit root tests (DF and $\mathrm{ADF}$ ), there are many other tests in the literature, such as that of Zivot and Andrews.

The main difference between the ADF and Zivot and Andrews tests is in relation to the presence of the structural break. Zivot and Andrews (1992) developed the unit root test with the possibility of breaking, being that test considers only the possibility of structural break in the alternative hypothesis $\left(H_{1}\right)$ (BLACK, 2016).

According to Shikida et al. (2016) the Zivot and Andrews test verifies the relationship between unit root and structural break, allowing the endogenous estimation of the structural break.

According to Waheed et al. (2007) to test the unit root hypothesis, Zivot and Andrews (1992) used the following equations corresponding to the three models:

$Z_{t}$ with a change in level:

$$
Z_{t}=\mu+\beta t+\theta D U_{t}+\alpha Z_{t-1}+\sum_{j=1}^{k} c_{j} \Delta Z_{t-j}+\epsilon_{t}
$$

$Z_{t}$ with change in slope:

$$
Z_{t}=\mu+\beta t+\gamma D T_{t}+\alpha Z_{t-1}+\sum_{j=1}^{k} c_{j} \Delta Z_{t-j}+\epsilon_{t}
$$

$Z_{t}$ with change in level and slope:

$$
Z_{t}=\mu+\beta t+\theta D U_{t}+\gamma D T_{t}+\alpha Z_{t-1}+\sum_{j=1}^{k} c_{j} \Delta Z_{t-j}+\epsilon_{t}
$$

where $D U$ is a variable dummy of indicator for an average change that occurs at each possible interruption date $(T B)(1<T B<T)$. While $D T$ is a corresponding trend change variable, with

$$
\left\{\begin{array} { l } 
{ D U _ { t } = 1 , \text { if } t > T B } \\
{ 0 , \text { otherwise } }
\end{array} \quad \left\{\begin{array}{l}
D T_{t}=t-T B, \text { if } t>T B \\
0, \text { otherwise. }
\end{array}\right.\right.
$$

In each equation, the hypotheses to be tested are:

$$
\left\{\begin{array}{l}
H_{0}: \alpha=0, \text { presence of unit root } \\
H_{1}: \alpha<0, \text { stationarity with structural change to some point. }
\end{array}\right.
$$

Then, from the 3 equations $\left(28,29\right.$ e 30), the null hypothesis $H_{0}$ is rejected if the calculated statistic is less than the critical value in the Zivot and Andrews statistics (TEIXEIRA; MAIA, 2008).

Furthermore, according to Margarido (2001) conventional unit root tests of the type Augmented Dickey-Fuller (ADF) and Phillips-Perron (PP) are not indicated in the presence of structural breaks, as they lead to biased results in relation to stationarity or not from the series. 


\subsection{Data analysis}

First, the series and the autocorrelation functions were graphically analyzed, using the software R (R CORE TEAM, 2019). Then, it was verified whether the series needed any transformation using software Gretl (GRETL, 2012).

For methodological reasons, it was first verified the presence of seasonality in the series, and then to proceed with the analysis of the trend component.

Then, the presence of the seasonal component was analyzed, using Fisher test (1929). According to Morettin and Toloi (2018), the trend tests are performed in the absence of seasonality.

Thereafter, the 4 databases were analysed through trend tests. The Pettitt, Run, Mann-Kendall, Cox-Stuart tests and the unit root tests (Dickey-Fuller, ADF and Zivot and Andrews) were applied to all series under study, in order to verify which tests were able to detect the presence or absence of the trend component, with the respective values of the statistics and the critical values. From these values, it was concluded about the stationarity or not of the series.

The analyses were performed in the software $\mathrm{R}$, using the respective packages : trend for the Pettitt, Mann-Kendall and Cox-Stuart tests, randtests for the Run test and urca for the Dickey-Fuller, Augmented Dickey-Fuller and Zivot and Andrews tests.

\section{Results and discussion}

To development of the analysis in relation to the 4 time series through trend tests, it was necessary to analyze the seasonal component as mentioned earlier.

Thus, through the application of Fisher test, it was observed that the series under study did not present the seasonal component $(p$-value $<0.05)$, except for the temperature series $(p$-value $>0.05)$.

Moreover, all the models that characterized the series studied were additives, according to the $t$-test to verify the need for transformation.

Based on this information, the trend tests were applied to the four series studied and the results obtained for each series are described below.

\subsection{Maximum temperature in the city of Lavras}

The maximum temperature series in the city of Lavras (Minas Gerais, Brazil) was the first to be analyzed. Figure 1 shows the series and the autocorrelation function $(\mathrm{ACF})$ plots.

Rev. Bras. Biom., Lavras, v.39, n.2, p.311-333, 2021 - doi: 10.28951/rbb.v39i2.471 

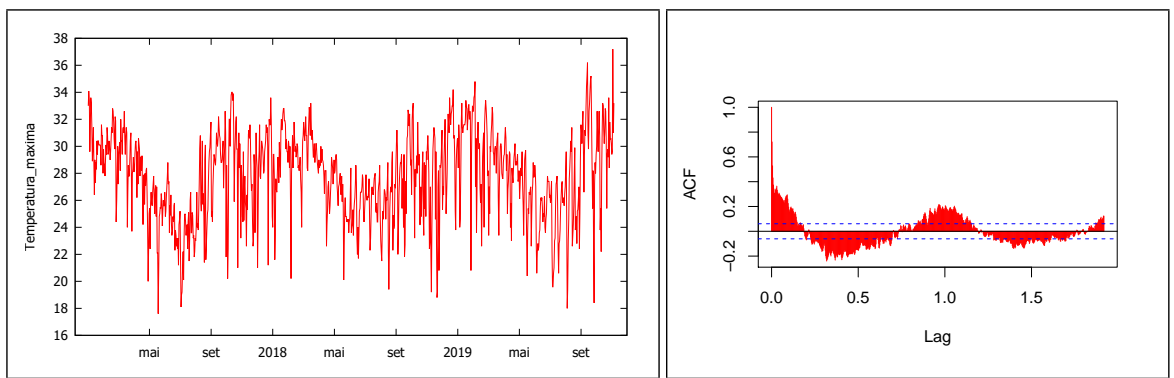

Figure 1 - (a) Maximum temperature in the city of Lavras. (b) ACF.

It was verified by analyzing the original series and the ACF (Figure 1) plots the value of the observations increases and decreases over time. Therefore, it is suggested that the seasonality component is present in the model, indicating nonstationarity.

The results for the trend tests in relation to the temperature series are presented below. In addition, seasonality was removed from this series, as indicated by Morettin and Toloi (2018) "if there is another component (such as seasonality) in the series, in addition to the trend, it is eliminated before testing for the presence of trend".

For all tests it was considered $\alpha=5 \%$ (TABLE 1). In addition, the critical value $\tau$ for the $\mathrm{ADF}$ test is calculated according to the number of observations, different from the non-parametric tests ( $Z$ statistic) and the Zivot and Andrews test ( $t$ statistic) in which the critical value is a fixed value.

Table 1 - Results of the trend tests for the temperature series

\begin{tabular}{cccc}
\hline Tests & Statistics & Critical Value & Conclusion \\
\hline Run & -15.55 & 1.96 & There is a trend \\
Mann-Kendall & 1.76 & 1.96 & There is no trend \\
Cox-Stuart & 0.32 & 1.96 & There is no trend \\
ADF & -15.42 & -3.41 & There is no unit root \\
Zivot e Andrews & -17.01 & -5.08 & There is no unit root \\
\hline
\end{tabular}

The Mann-Kendall test, indicated according to Goossens and Berger (1986, apud Back (2001)) when it comes to climate series, rejected the presence of the trend component along with the unit root and Cox-Stuart tests. Thus, diverging from the Run test. In addition, according to Morettin and Toloi (2018), the Run and Cox-Stuart tests should be used with caution.

In the study of Barbosa et al. (2015) also referring to temperature (monthly), the authors presented similar results, as they reported the presence of additive 
seasonality and the absence of a trend in the data, being confirmed through Fisher test and the ADF test, respectively.

Through the Mann-Kendall test, Denski and Back (2015) used series of temperature data, and they did not found trend in the maximum monthly temperature, and finding a trend only in the series of average annual temperature. Then, it was noted that the study mentioned above corroborated with the analysis of the maximum temperature series in the city of Lavras.

However, the Run test detected the presence of trend and this may be related to the fact that the series presents only the significant deterministic trend, although it was not detected through the ADF test.

Verifying this suposition in relation to the deterministic trend, a regression analysis was performed. The linear model was the one that best adjusted to the data, confirming the presence of a significant linear trend, but a value close to zero. Thus, maybe because of this, the ADF test was not able to detect this component for the angular coefficient.

Regarding the Pettitt, Zivot and Andrews (ZA) test, there is the presence of the point of change and the structural break, respectively. The point of change found through the Pettitt test is related to the central trend of a series. While for the ZA test, the structural break point is related to the maximum or minimum of the function.

Figure 2 presents the maximum temperature series with the point of change by means of the Pettitt test and the time series of the T statistic of the ZA test for the detection of structural break.

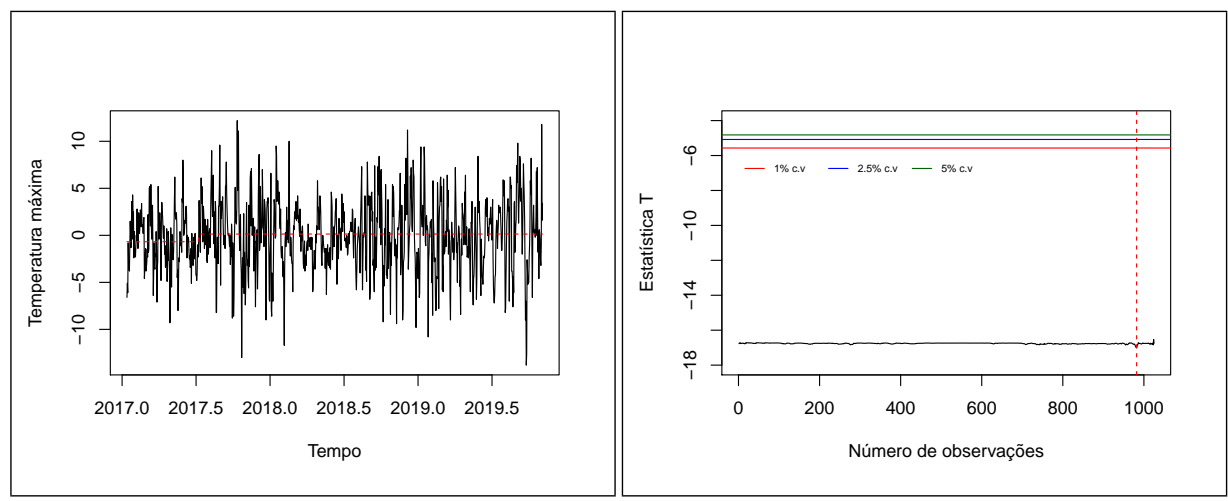

Figure 2 - (a) Maximum temperature series with the change point. (b) Time series of the T statistic.

In addition, the Pettitt test presented a point of change, $k=177$, referring to the day $06 / 26 / 2017$ with the temperature value equal to $22.4^{\circ} \mathrm{C}$, as can be seen in Figure 2 (a). For the ZA test, this point was located in the position 982 referring to the date 09/09/2019 (FIGURE 2 (b)). The maximum temperature for that day 
was equal to $30.8^{\circ} \mathrm{C}$, diverging from the value referred to by the Pettitt test. The tests differed in relation to the point of change and this can be justified by the fact that the generating process for each test is different.

\subsection{Unemployment rate in the Metropolitan Region of São Paulo}

The second series analyzed was the unemployment rate in the Metropolitan Region of São Paulo. The unemployment rate and its autocorrelation function are shown in Figure 3.
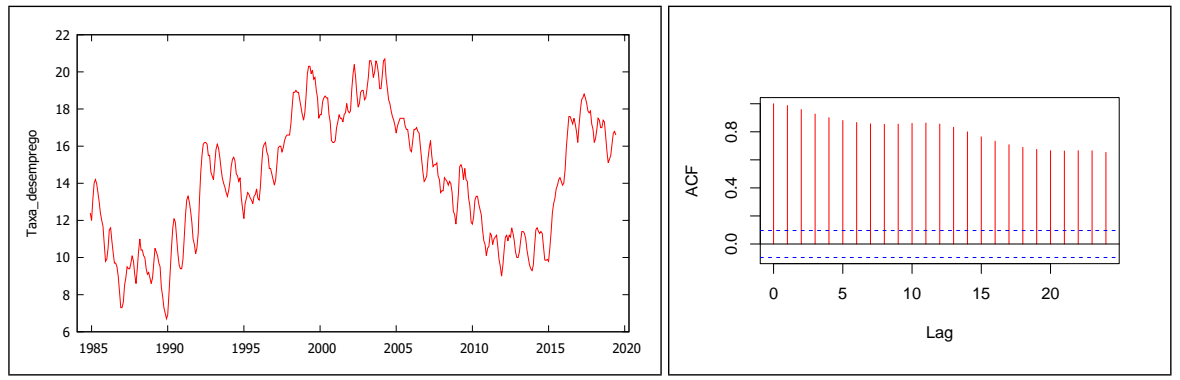

Figure 3 - (a) Unemployment rate in the Metropolitan Region of São Paulo. (b) ACF.

Through Figure 3 (a) it was verified that the series presents a long period increase and another of decrease which indicates a trend. In addition, it was observed through the ACF that the series is non-stationary (FIGURE 3 (b)).

From this, the results of the trend tests for the unemployment series are presented below (TABLE 2).

Table 2 - Results of the trend tests for the unemployment series

\begin{tabular}{cccc}
\hline Tests & Statistics & Critical Value & Conclusion \\
\hline Run & -18.26 & 1.96 & There is a trend \\
Mann-Kendall & 5.23 & 1.96 & There is a trend \\
Cox-Stuart & 5.92 & 1.96 & There is a trend \\
ADF & -3.16 & -3.42 & There is the presence of a unit root \\
Zivot e Andrews & -4 & -5.08 & There is the presence of a unit root \\
\hline
\end{tabular}

Based on results from Table 2, it was found through unit root tests, ADF and Zivot and Andrews, that the series showed a stochastic trend and the series is integrated of order one, and a difference is required for it to become stationary. 
Furthermore, for the unemployment series, all tests accepted the hypothesis of the presence of the trend component. In a similar study, but with a smaller number of observations (in the period from 1985 to 2010), Marques and Fava (2011) showed that the unemployment series in the Metropolitan Region of São Paulo presented seasonality and also a stochastic trend, being confirmed through of the ADF unit root test.

However, Ferrari and Brasil (2015) reported divergent results for the stochastic trend, because through tests of stationarity in panels they rejected the presence of unit root, indicating that the shocks on the unemployment rates of the Brazilian states have transitory effects and converge to a long-term equilibrium.

Thus, knowing that the unemployment series presented the trend component through the tests studied, there are the points of change resulting from the Pettitt test (FIGURE 4 (a)) and ZA test (FIGURE 4 (b)).

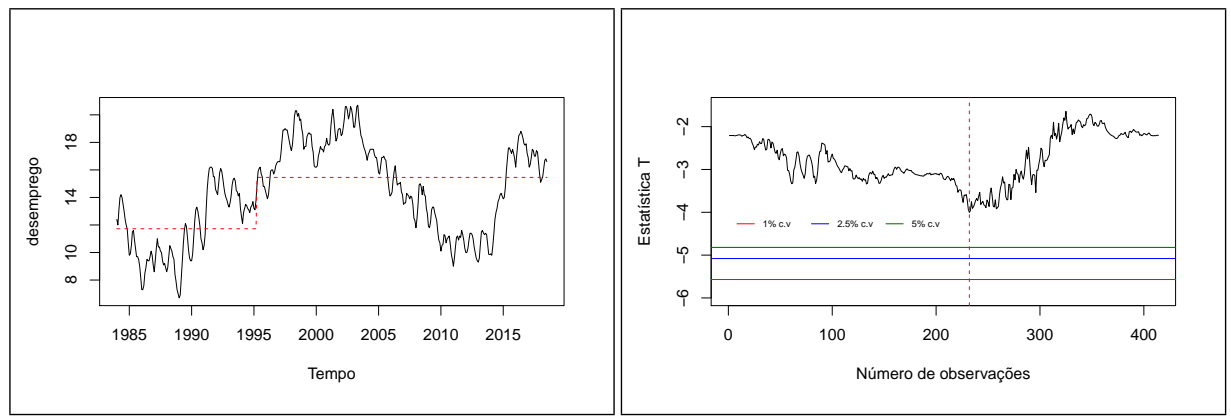

Figure 4 - (a) Series of unemployment with the change point. (b) Time series of the T statistic.

Through the Pettitt test, the series presented a change in rupture in time $k=135$, which can be seen in Figure 4 (a), referring to February 1996 (value equal to $13.8 \%$ ).

The structural break point obtained through the Zivot and Andrews test is a minimum point and is in the position 232 (FIGURE $4(\mathrm{~b})$ ). The point refers to the month of March 2004 with an amount equal to 20.6, once again diverging from the amount referred to by the Pettitt test.

In addition, the point found has no practical meaning, since in this specific month there was no shock in relation to the unemployment rate in Brazil.

\subsection{IPCA}

The next series analyzed was the inflation series, referring to the Broad National Consumer Price Index (IPCA). The series and its autocorrelation function (ACF) (FIGURE 5) are presented below.

Rev. Bras. Biom., Lavras, v.39, n.2, p.311-333, 2021 - doi: 10.28951/rbb.v39i2.471 

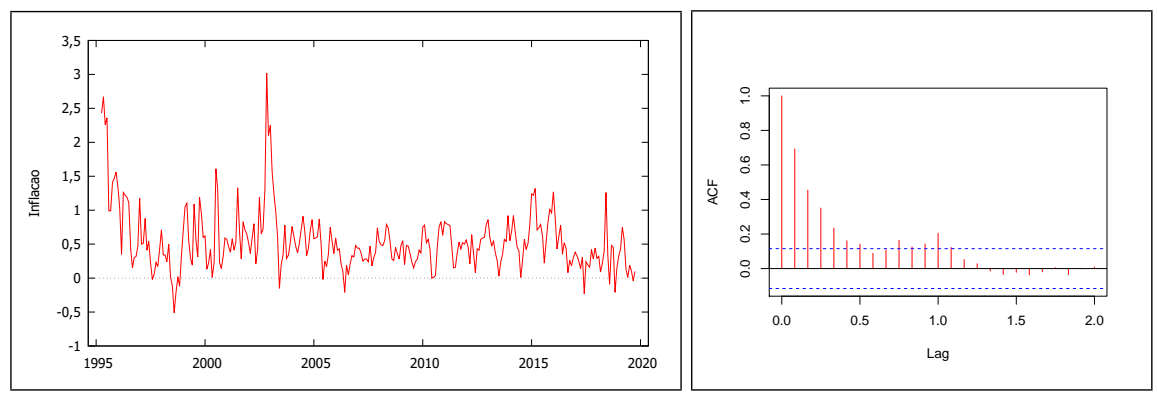

Figure 5 - (a) IPCA series. (b) ACF.

Based on the Figure 5 (a), it was observed that the values of the series increase and decrease over time. In addition, the analyzed range of the IPCA series is related to the era of the real plan, which was implemented in Brazil in February 1994.

Also analyzing the ACF of the inflation series, the observations slowly decline to zero, which characterizes a non-stationary series (FIGURE 5 (b)).

For the inflation series, the tests differed in relation to the presence or not of the trend component, as can be seen in Table 3 .

Table 3 - Results of the trend tests for the inflation series

\begin{tabular}{cccc}
\hline Tests & Statistics & Critical Value & Conclusion \\
\hline Run & -7.32 & 1.96 & There is a trend \\
Mann-Kendall & -2.58 & 1.96 & There is a trend \\
Cox-Stuart & 2.21 & 1.96 & There is a trend \\
ADF & -7.79 & -3.42 & There is no unit root \\
Zivot e Andrews & -8.64 & -5.08 & There is no unit root \\
\hline
\end{tabular}

Like the temperature series, the Broad Consumer Price Index series rejected the presence of a unit root through the ADF test and Zivot and Andrews test, that is, the series did not show a stochastic trend. In addition, the ADF test did not show a significant value $(p$-value $>0.05)$ in relation to the estimation of the deterministic trend.

The other tests applied, Run, Mann-Kendall and Cox-Stuart, did not reject the presence of the trend component, which suggests that these tests verify the presence of the deterministic trend.

Through the Pettitt test, the point of change of the series occurred at time $k=122$, referring to May 2005, as can be seen in Figure 6 (a). The inflation rate for that month was equal to $0.49 \%$. For the Zivot and Andrews test, the break date found in this work was November 1998 (FIGURE 6 (b)). 

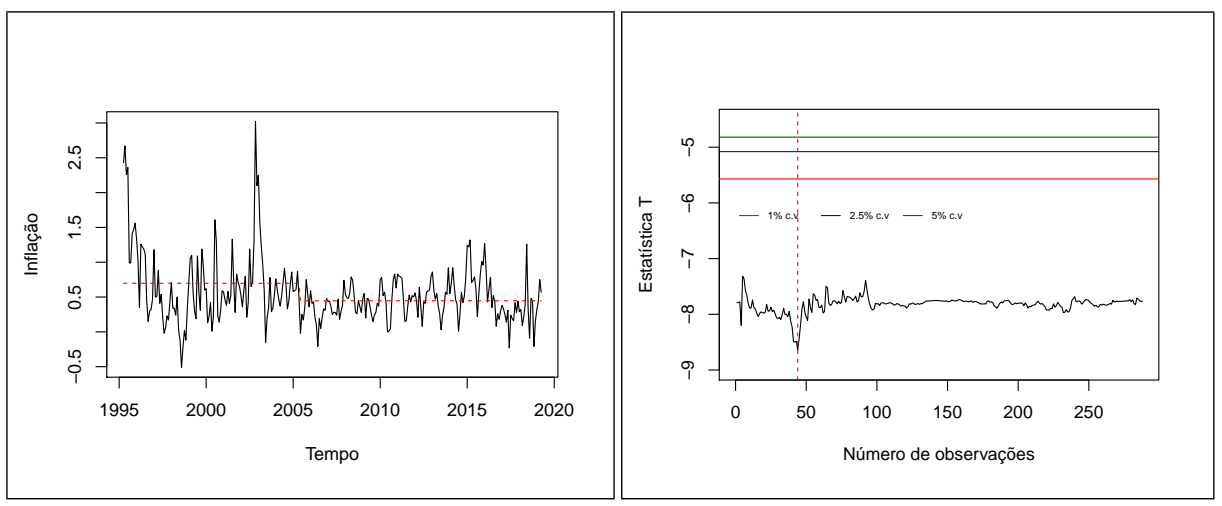

Figure 6 - (a) Inflation series with the change point. (b) Time series of the $\mathrm{T}$ statistic.

Thus, it was noticed that the points of change and structural break diverged in relation to the tests of Pettitt and Zivot and Andrews and again, this can be justified by the fact that the generating process of each test is different.

\subsection{Brazilian GDP (in trillions of dollars)}

The last analyzed series refers to the data of the Brazilian nominal Gross Domestic Product (GDP). Figure 7 presented the series and its autocorrelation function $(\mathrm{ACF})$.
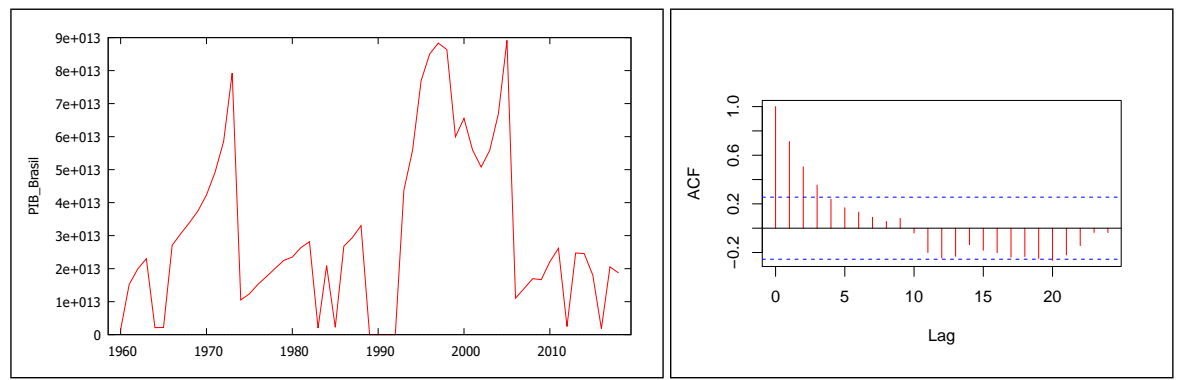

Figure 7 - (a) Brazilian GDP (US \$). (b) ACF.

It was observed through Figure 7 (a) that the series presented a non-stationary behavior, since the values presented a increase and decrease over time. In addition, unlike climatic series, macroeconomic series have effects of policies, of economic crisis, so it was observed some peaks in the series due to these factors. For example, 
the peak of the 1970s is related to the time of the "economic miracle", a time when the economy grew at very high rates.

Analyzing the ACF (Figure 7 (b)) of the Brazilian GDP series, the behavior of a non-stationary series was observed once again.

After these analyses, verification started through the trend tests. Table 4 presents the results for the Brazilian Gross Domestic Product series.

Table 4 - Results of the trend tests for the GDP series

\begin{tabular}{cccc}
\hline Tests & Statistics & Critical Value & Conclusion \\
\hline Run & -6.09 & 1.96 & There is a trend \\
Mann-Kendall & 1.43 & 1.96 & There is no trend \\
Cox-Stuart & 0.53 & 1.96 & There is no trend \\
ADF & -2.75 & -3.42 & There is the presence of a unit root \\
Zivot e Andrews & -5.04 & -5.08 & There is the presence of a unit root \\
\hline
\end{tabular}

It is noted that the GDP series showed a stochastic trend through the ADF test and Zivot and Andrews test. However, the Mann-Kendall and Cox-Stuart tests rejected the hypothesis of the presence of the trend component, diverging from the other tests.

According to Margarido and Anefalos (1999), economic series, in especial macroeconomic, most often present a non-stationary behavior.

Despite the tests diverging in relation to the presence of the trend component, on the other hand, the structural breaks found through the Pettitt test and Zivot and Andrews test for the GDP series were equal. This result can be observed in Figure 8.
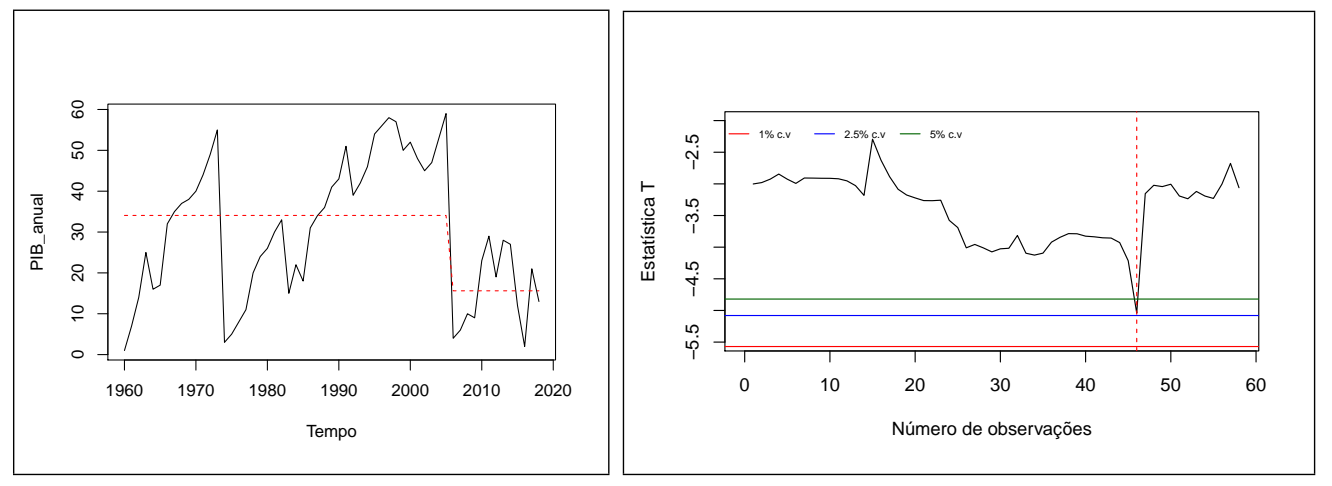

Figure 8 - (a) Brazil GDP series with the change point. (b) Time series of the $\mathrm{T}$ statistic. 
For the two tests, ZA and Pettitt, presented a point of change in position 46, being refers to the year $2005(12 / 31 / 2005)$ with approximate value of 89.2 trillion dollars (FIGURE 8).

\subsection{Synthesis}

Through the analyses carried out by means of the trend tests, a summary of the tests for the 4 series was presented in Table 5 .

Table 5 - Summary of trend tests

\begin{tabular}{ccccc}
\hline $\begin{array}{c}\text { Series/ } \\
\text { Tests }\end{array}$ & $\begin{array}{c}\text { Temperature } \\
\text { trend }\end{array}$ & $\begin{array}{c}\text { Unemployment } \\
\text { trend }\end{array}$ & $\begin{array}{c}\text { Inflation } \\
\text { trend }\end{array}$ & $\begin{array}{c}\text { PIB } \\
\text { trend }\end{array}$ \\
\hline Run & yes & yes & yes & yes \\
Mann-Kendall & no & yes & yes & no \\
Cox-Stuart & no & yes & yes & no \\
ADF & no & yes & no & yes \\
Zivot e Andrews & no & yes & no & yes \\
\hline
\end{tabular}

The Pettitt test is not present in Table 5, since the purpose of the test is to show the point of change and whether that point is significant or not. All points of change found through the Pettitt test were significant at $5 \%$.

Regarding the Dickey-Fuller test and ADF test, it was found that the ADF test was used for all the series under study, temperature, unemployment, inflation and the GDP series. When using the DF test and it is verified that in the model analyzed the errors are autocorrelated, the number of lags must be increased and the ADF test must be worked on.

Although Maddala and Kim (1998), report that the use of the Dickey-Fuller and ADF tests with the possibility of structural break can bring biased results, this was not observed with the series evaluated in the present study. The results found were similar in relation to the presence or not of the stochastic trend compared to the Zivot and Andrews test, as can be seen in Table 5

Moreover, in this study 3 unit root tests (DF, ADF and Zivot and Andrews) were presented, however, there are several others in the literature that verify the presence of more than one structural break, which can be investigated in future studies.

\section{Conclusions}

The results presented differences between the trend tests applied to different areas, demonstrating that they differ according to the characteristics inherent to each series and to the test generating process. 
For the temperature series it is recommended to use the Mann-Kendall test, which is a reference for climatic series. Most studies shown the presence of the trend component is not a characteristic of climatic series.

For the unemployment series it is recommended to use unit root tests, although all tests present similar results. Moreover, the presence of a unit root is a characteristic of economic series.

Regarding the inflation series, the unit root tests did not present a stochastic trend. The other tests reported the presence of the trend, which suggests that the process that generates these tests verifies the presence of the deterministic trend.

For the GDP series, the Mann-Kendall and Cox-Stuart tests did not present a trend and diverged from the others. Thus, for the GPD series the unit root tests are recommended, as indicated in the literature.

Due to a large number of trend tests, it becomes very important to identify the test that best depicts the behavior of the series characteristics, since tests applied incorrectly can bias the results. This happens when the researcher analyes a series with the presence of a deterministic trend and, instead of eliminating this component through estimation, uses a difference that is the method indicated when the series presents a stochastic trend.

Therefore, for these specific series, the test results (Mann-Kendall, ADF and Zivot and Andrews) found are in accordance with the literature. For the other tests, a deeper study is necessary, not carried out in this research, but taking into account some information described in the course of the article.

\section{Acknowledgments}

We would like to thank reviewers and editors for their comments and suggestions. The authors would also like to thank the doctoral scholarship granted by CAPES to the first author.

PAIVA, D. A.; SÁFADI, T. Estudo de testes para tendência em Séries Temporais. Rev. Bras. Biom., Lavras, v.39, n.2, p.311-333, 2021. 
- RESUMO: A metodologia de séries temporais é uma importante ferramenta quando se utiliza dados ao longo do tempo. A série temporal pode ser composta pelas componentes tendência $\left(T_{t}\right)$, sazonalidade $\left(S_{t}\right)$ e o erro aleatório $\left(a_{t}\right)$. Nesse sentido, este trabalho tem como objetivo estudar os testes utilizados para analisar a componente tendência, os quais foram: Pettitt, Run, Mann-Kendall, Cox-Stuart e os testes de raiz unitária (Dickey-Fuller, Dickey-Fuller Aumentado e Zivot e Andrews), dado que existe discrepância entre os resultados dos testes encontrados na literatura. As quatro séries analisadas foram a temperatura máxima na cidade de Lavras, taxa de desemprego na Região Metropolitana de São Paulo (RMSP), Índice de Preços ao Consumidor Amplo (IPCA) e o Produto Interno Bruto (PIB) nominal do Brasil. Verificou-se que os testes de raiz unitária apresentaram resultados análogos em relação à presença da tendência estocástica para todas as séries. Além disso, o ponto de mudança do teste de Pettitt divergiu de todas as quebras estruturais encontradas através do teste de Zivot e Andrews, exceto em relação à série do PIB. Portanto, constatou-se que os testes de tendência divergiram entre si, obtendo resultados similares somente em relação à série de desemprego.

- PALAVRAS-CHAVE: Séries econômicas; série de temperatura; tendência estocástica e determinística.

\section{References}

ALVES, F. de A. Comparação de testes de raiz unitária e cointegração em modelos de longa dependência, 2008. 58p. Dissertação (Mestrado em Estatística) - Universidade Federal de Minas Gerais, Belo Horizonte, 2008.

AMARAL, M. V. S. G. Ajuste de modelos e comparação de séries temporais para dados de vazão específica em microbacias pareadas, 2014. 92p. Dissertação (Mestrado em Estatística e Experimentação Agronômica) - Universidade de São Paulo, Piracicaba, 2014.

ANTUNES, J. L. F.; CARDOSO, M. R. A. Uso da análise de séries temporais em estudos epidemiológicos. Epidemiologia e Serviços de Saúde, Brasília, v.24, n.3, p.565-576, 2015.

BACK, Á. J. Aplicação de análise estatística para identificação de tendências climáticas. Pesquisa Agropecuária Brasileira, Brasília, v.36, n.5, p.717-726, 2001.

BARBOSA, E. C. et al. Metodologia Box \& Jenkins para previsão de temperatura média mensal da cidade de Bauru (SP). Revista Brasileira de Biometria, Lavras, v.33, n.1, p.104-117, 2015.

BARBIERI, L. F. P.; CORREIA, M. de F.; ARAGÃO, M. R. da S.; VILAR, R. de A. A.; MOURA, M. S. B. Impact of climate variations and land use change: A Mann-Kendall Application. Revista Geama, Recife, v.3, n.3, p.127-135, 2017.

BLACK, C. Tendência, quebra estrutural e persistência dos choques no preço da soja de 1960 a 2014. Indicadores Econômicos FEE, Porto Alegre, v.43, n.3, p.9-26, 2016 .

Rev. Bras. Biom., Lavras, v.39, n.2, p.311-333, 2021 - doi: 10.28951/rbb.v39i2.471 
DENSKI, A. P. N.; BACK, Á. J. Tendência climatológica nos elementos meteorológicos e na evapotranspiração de referência de Urussanga-SC. Revista Brasileira de Climatologia, Curitiba, v.17, p.259-271, 2015.

DICKEY, D. A.; FULLER, W. A. Distribution of the estimators for autoregressive time series with a unit root. Journal of the American statistical association, EUA, v.74, n.366a, p.427-431, 1979.

DICKEY, D. A.; FULLER, W. A. Likelihood ratio statistics for autoregressive time series with a unit root. Econometrica: Journal of the Econometric Society, New York, v.49, n.4, p.1057-1072, 1981.

ENDERS, W. Applied econometric time series. 4. ed. EUA: J. Wiley, 2008. 498p.

FERRARI, T. K.; BRASIL, G. H. Comportamento do desemprego regional no Brasil: uma aplicação de teste de convergência em painel. Nova Economia, Belo Horizonte, v.25, n.3, p.673-688, 2015.

FISHER, R. A. Tests of significance in harmonic analysis. Proceedings of the Royal Society of London, Londres, v. 125, n.796, p.54-59, 1929.

GRETL. Gretl user's guide. 2012. http://gretl.sourceforge.net.

LIMA, J. R.; SILVA, J. de S.; SANTOS, R. K. B. Comportamento dos preços da manga exportada do Brasil: 2004-2012. Organizaçôes Rurais $\&$ Agroindustriais, Lavras, v.15, n.3, p.370-380, 2013.

MADDALA, G. S.; KIM, I. M. Unit roots, cointegration, and structural change. 4.ed. New York: Cambridge University, 1998. 505p.

MANN, H. B. Nonparametric tests against trend. Econometric Society, New Haven, v.13, n.3, p.245-259, 1945.

MARGARIDO, M. A. Aplicação de testes de raiz unitária com quebra estrutural em séries econômicas no Brasil na década de 90. Informações econômicas, São Paulo, v.31, n.4, p.7-22, 2001.

MARGARIDO, M. A.; ANEFALOS, L. C. Testes de raiz unitária e o software SAS. Agricultura em São Paulo, São Paulo, v.46, n.2, p.19-45, 1999.

MARQUES, G. d. O.; FAVA, V. L. Persistência e memória longa sazonal na série de desemprego da região metropolitana de São Paulo. Economia Aplicada, Ribeirão Preto, v.15, n.2, p.177-198, 2011.

MOREIRA, J. d. V.; NAGHETTINI, M. Detecção de tendências monotônicas temporais e relação com erros dos Tipos I e II: estudo de caso em séries de precipitações diárias máximas anuais do Estado do Acre. Revista Brasileira de Meteorologia, São José dos Campos, v.31, n.4, p.394-402, 2016.

MORETTIN, P. A.; TOLOI, C. M. Análise de Séries Temporais: modelos lineares univariados. 3.ed. São Paulo: Blucher, 2018. 474p.

NIEL, H. L. et al. Variabilité climatique et statistiques: Etude par simulation de la puissance et de la robustesse de quelques tests utilisés pour vérifier l'homogénéité de chroniques. Revue des sciences de l'eau, Quebec, v.11, n.3, p.383-408, 1998. 
PENEREIRO, J. C.; MESCHIATTI, M. C. Tendências em séries anuais de precipitação e temperaturas no Brasil. Engenharia Sanitária e Ambiental, Rio de Janeiro, v.23, n.2, p.319-331, 2018.

PENEREIRO, J. C.; ORLANDO, D. V. Análises de tendências em séries temporais anuais de dados climáticos e hidrológicos na bacia do Rio Parnaíba entre os estados do Maranhão e Piauí/Brasil. Revista Geográfica Acadêmica, Boa Vista, v.7, n.2, p.5-21, 2013.

PETTITT, A. A non-parametric approach to the change-point problem. Journal of the Royal Statistical Society, Malden, v.28, n.2, p.126-135, 1979.

POERSCHKE, R. P.; MORAIS, I. A. C. d. Determinantes da demanda brasileira por importação de arroz: uma abordagem não linear. Revista de Economia e Sociologia Rural, Piracicaba, v.52, n.1, p.177-194, 2014.

R Core Team (2019). R: A language and environment for statistical computing. R Foundation for Statistical Computing, Vienna, Austria. URL https://www.Rproject.org/.

SAlVIANO, M. F.; GROPPO, D. J.; PEllEGRINO, G. Q. Análise de tendências em dados de precipitação e temperatura no Brasil. Revista Brasileira de Meteorologia, São José dos Campos, v.31, n.1, p.64-73, 2016.

SHIKIDA, C.; PAIVA, G. L.; JUNIOR, A. F. A. Análise de quebras estruturais na série do preço do boi gordo no estado de São Paulo. Economia Aplicada, Ribeirão Preto, v.20, n.2, p.265-286, 2016.

TEIXEIRA, G. d. S.; MAIA, S. F. Impacto da febre aftosa no preço da arroba do boi gordo, recebido pelo produtor no Brasil. Revista de Economia e Agronegócio, Viçosa, MG, v.6, n.2, p.195-214, 2008.

WACKERLY, D.; MENDENHALL, W.; SCHEAFFER, R. L. Mathematical Statistics with Applications. 7.ed. EUA: Cengage Learning, 2014. 939p.

WAHEED, M.; ALAM, T.; GHAURI, S. P. Structural breaks and unit root: evidence from pakistani macroeconomic time series. Available at SSRN 963958, Rochester, p.19, 2007.

ZIVOT, E.; ANDREWS, D. W. K. Further evidence on the great crash, the oil-price shock, and the unit-root hypothesis. Journal of Business \& Economic Statistics, Alexandria, v.10, n.3, p.251-270, 1992.

Received on 24.04.2020.

Approved after revised on 05.08.2020.

Rev. Bras. Biom., Lavras, v.39, n.2, p.311-333, 2021 - doi: 10.28951/rbb.v39i2.471 